\title{
The level of diversification on the firms of the Iberian market
}

\author{
GUALTER COUTO \\ School of Business and Economics, University of Azores and CEEAplA \\ 9500-321 Ponta Delgada \\ PORTUGAL \\ JOÃO CABRAL \\ School of Business and Economics, University of Azores \\ 9500-321 Ponta Delgada \\ PORTUGAL \\ PEDRO PIMENTEL \\ School of Business and Economics, University of Azores and CEEAplA \\ 9500-321 Ponta Delgada \\ PORTUGAL \\ RUI ALEXANDRE CASTANHO \\ Faculty of Applied Sciences, WSB University \\ 41-300 Dabrowa Górnicza \\ POLAND \\ and \\ College of Business and Economics, University of Johannesburg \\ PO Box 524, Auckland Park \\ SOUTH AFRICA
}

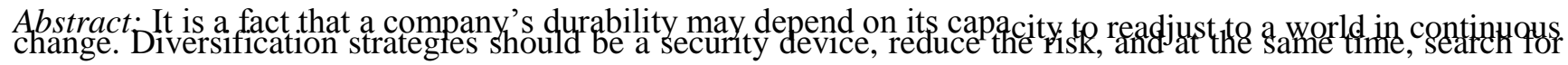
possible profitable opportunities. Therefore, when a diversified firm follows one of its business sections and realizes that the performance is worse than foreseen, this negative impact may be diminished by other segments with better performance. Contextually, the current study aims to determine a correlation between value and corporate diversification in the Iberian market. We use Tobin's $Q$ as the measure for value and the Herfindahl Index to measure diversification. In addition to the study of correlation, this paper also analyses the level of diversification for the firms that integrate the Iberian market and if their market value is above or below their book value. Using these metrics, we found a negative correlation between value and diversification in the Iberian Market. In our sample, we also found that highly diversified firms performed worse than focused firms on average. In the Portuguese sample, we were able to determine the level of diversification that maximizes the Tobin's Q of a firm. According to Tobin's Q, our sample was characterized by a low level of diversification in general and that the companies were slightly overvalued.
\end{abstract}

Key-Words: Tobin's Q; Herfindahl Index; Corporate Refocusing; Diversification

Received: November 27, 2020. Revised: May 16, 2021. Accepted: June 1, 2021. Published: June 7, 2021.

\section{Introduction}

In a world of constant change and uncertainty, a company's survival may depend on its ability to adapt [1-3]. The strategy of diversification can be either a defence mechanism, reducing unique risk, or exploring possible profitable opportunities, or both at the same time [1-4]. When a diversified firm watches one of its business segments perform worse than expected, this negative impact may be softened by other segments with better performance [1]. 
In this study, we determine the firms' diversification level that integrates the Iberian markets and then observe how much impact it has on a company's valuation. Unlike in the North American and European literature, there are few studies about the Iberian markets' diversification strategy. To fulfil this gap and better understand the impact of diversification in the Iberian Peninsula, compared to other markets, this study has been conducted to analyse and compare three different markets between each other (Portugal, Spain, and Iberian Peninsula as a whole) and test Santalo and Becerra's [5] premise. Their study claims that the relationship between corporate value and diversification is not static and depends on a series of factors that vary from market to market. In this study, we corroborate such a hypothesis, showing different behaviours between the Portuguese and Spanish markets, which leads us to assume the impact of a diversification strategy on corporate value. However, the nature of that same impact is uncertain and may depend on a variable series of factors.

Contextually, Rumelt [6] and Wemerfeld and Montgomery [7] defend that a diversification strategy provides value creation through synergies and cost distribution across segments. Villalonga's [8] study reveals the opposite, but when adjusting and refining its diversification measures, Villalonga finds a premium caused by diversification. Hadlock, Ryngaert, and Thomas [9] also add that when a firm issues stock to raise capital, the negative impact caused by stock dilution is lower if the firm is diversified.

On the other hand, some authors claim that the diversification strategy destroys value. The Tobin's $\mathrm{Q}$ is systematically lower, and the value of the firm as a whole is also lower when compared to the sum of its segments (see: Morck, Shleifer, and Vishny [10], Scharfstein [11], Maksimovic, and Phillips [12]). Lebaron and Speidell [13] branded this phenomenon and the process of dismantling and selling each segment as a standalone firm as the "Chop Shop Approach." In addition to these authors, Comment and Jarrel [14] also mention that diversify is influenced by the managers' motives. To reduce their risk, managers look for alternate sources of income in different business areas, which could reduce shareholder value. Also, according to Sayrak and Martin [15], sometimes less profitable and efficient segments may be eating away a firm's resources, while other segments with more growth potential or efficiency are being neglected, impacting the firm's productivity levels negatively.

Finally, some authors believe that such a strategy's impact may vary according to how it is implemented [16] and the market where the firm operates [5]. Markides [17] and Santarelli and Tran [18] also add that every company has a level of diversification that maximizes its value, where if a company over diversifies, its value will decrease.

The sample used in the present study allows us to analyse the Iberian markets in a period of recession (2010 to 2012).

The rest of the paper is organized as follows. Chapter 2 describes the methodology that was used. In Chapter 3 we present the results from applying the methodology to our sample. Lastly, in Chapter 4 we include our concluding remarks.

\section{Methodology}

The methodology used is based on Lang and Stulz [19] and Carvalho Maia and Barbedo [20], which consists of establishing a relation between diversification (Herfindahl Index) and corporate value (Tobin's Q). The Herfindahl Index is constructed by using in-formation about the firms' number of segments. Simultaneously, Tobin's Q is based on the firms' reports and markets' information. Once these metrics are correctly constructed, we run a series of statistical tests that allow us to study the relationship between both metrics to conclude the type of relation between diversification and corporate value in the sample used.

The Herfindahl Index is the summation of each segment's revenue percentage, raised to the power of 2. The Herfindahl Index's formula can be described as follows:

(1)

$$
\text { HERFINDAHL INDEX }=\sum_{i=1}^{N}\left(\frac{R_{i}}{T R} \times 100\right)^{2}
$$

Where $R_{i}$ is the revenue of each segment, $T R$ is the firm's total revenue, and $i$ corresponds to each segment, which goes until $N$, the total number of segments where the company operates.

The information about the segments was obtained from the firms' annual reports. Since nearly every company has a different way to categorize its own business segments, we opted for normalizing our sample according to a unique pattern of diversification. This way, it will be possible to compare the firms in the sample.

Tobin's Q [21] ratio determines whether a company is overvalued or undervalued in the market. It is calculated as the market value of a company divided by the replacement value of the firm's assets:

(2)

Tobin's $Q=\frac{\text { Total Market Value of the Firm }}{\text { Total Asset Value of the Firm }}$ 
The market value was calculated by multiplying the total number of common shares at the end of each year by the closing price on the last day of the year, added to debt component, with the information on each company's balance sheet being used as a proxy. The total value of the assets corresponds to the total net value of the asset presented in the accounting balance sheet for each company.

When there is a rise in a firm's $Q$ ratio after the firm diversifies, there is a diversification premium. It is considered an intangible asset for the firm, according to the market.

A Pearson's correlation was calculated for Tobin's Q, the Herfindahl Index, and the total number of segments for each of the three markets in the sample, the Portuguese, Spanish and Iberian markets. To determine the robustness of the results, we apply t--stu-dent's distribution tests to these samples. The results allow us to interpret and determine if there is a relation between the metrics used for diversification and corporate value in these markets.

In this phase, the firms are divided into three different groups: "Focalized firms," which only have one segment, and a Herfindahl Index equal to 1 . "Poorly diversified firms" with a low level of diversification and a Herfindahl Index between 0,6 and 1. Lastly, we have "Highly diversified firms," with a Herfindahl Index higher than zero and equal to or lower than 0,6 .

With these tests, we will be able to know which group of firms has a better performance. To statistically infer these results, we elaborate a hypothesis test for the means between the groups.

The model used by Markides [17] and Carvalho, Maia, and Barbedo [20] determines if the relationship between the metrics used in this study follows a quadratic function. If such a scenario is actual, it will either follow Coase's [22], Markides's [17] and Santarelli and Tran's [18] theory, or it will originate a parabola similar to the one found in Carvalho, Maia, and Barbedo's [20] study. The formula is given as follows:

(3)

$$
Q_{t, j}=\alpha+\beta_{1} H H I_{t, j}+\beta_{2} H H I_{t, j}^{2}+\varepsilon_{t, j}
$$

Where Q_ $(t, j)$ corresponds to the Tobin's Q of firm $\mathrm{j}$ in year $\mathrm{t}$ and 『HHI ${ }_{-}(\mathrm{t}, \mathrm{j})$ corresponds to the Herfindahl Index of firm $j$ in year $t$.

In case this type of relation exists, the graphic will either originate a concave parabola or a convex parabola. The first one indicates the existence of a point that maximizes value through diversification. If the firm raises its diversification level, it will suffer a reduction in its Tobin's Q.

In order to determine the marginal contribution of diversification on the value of a firm, a statistical model using dummy variables was constructed, with each dummy corresponding to the number of segments that compose the firm, as seen on Equation 4.

(4)

$$
Q_{t, j}=\alpha+\beta_{1} D(2)_{t, j}+\beta_{2} D(3)_{t, j} \ldots \beta_{k-1} D(k)_{t, j}+\varepsilon_{t, j}
$$

Where Q_ $(t, j)$ corresponds to firm j's Tobin's Q in year $t$ and $D(k)$ to the dummy variable relative to $\mathrm{k}$ segments that the company may at least have, with $\mathrm{k}=2,3,4,5,6,7,8,9,10$.

\section{Results and Discussions}

Contextually, three markets have been analysed in this study: (i) the Portuguese; (ii) the Spanish; and the (iii) Iberian market, which results in the combination of the first two. The sample is composed of 41 firms: 15 Portuguese and 26 Spanish firms. From this sample, we excluded firms directly related to financial services. All the information related to the firms' financial data was taken from their respective institutional websites, where all the annual reports for the years in the study are published.

The sample has a temporal horizon of 3 years, from 2010 to 2012, which allows us to study the relationship between diversification and value in a market going through an economic recession.

In Table 1, we can observe that the Iberian market is composed of firms with a low level of diversification since the Herfindahl Index is frequently around 8.000 points. Both countries show similar results regarding the means, although the level of focalization is more accentuated in the Portuguese market.

Table 1: Level of diversification in the Iberian Market, according to the Herfindahl Index. -

\begin{tabular}{|c|c|c|c|c|c|c|c|c|c|c|c|c|}
\hline & \multicolumn{4}{|c|}{ Portugal } & \multicolumn{4}{|c|}{ Spain } & \multicolumn{4}{|c|}{ Iberian Market } \\
\hline & 2010 & 2011 & 2012 & $\begin{array}{l}2010 \\
-2012\end{array}$ & 2010 & 2011 & 2012 & $\begin{array}{l}2010 \\
2012 \\
2\end{array}$ & 2010 & 2011 & 2012 & $\begin{aligned} 2010 \\
-2012\end{aligned}$ \\
\hline Mean & 8.5 & 8.6 & 8.5 & 8.5 & 7.6 & 7.9 & 8.1 & 7.9 & 7.9 & 8.2 & 8.2 & 8.1 \\
\hline
\end{tabular}
Statistical data. 


\begin{tabular}{|c|c|c|c|c|c|c|c|c|c|c|c|c|}
\hline Median & 8.1 & 8.1 & 8.3 & 8.1 & 8.0 & 8.9 & 9.2 & 8.6 & 8.0 & 8.4 & 8.8 & 8.3 \\
\hline $\begin{array}{l}\text { Standard } \\
\text { Deviation }\end{array}$ & 1.6 & 1.5 & 1.5 & 1.5 & 2.5 & 2.4 & 2.4 & 2.4 & 2.2 & 2.1 & 2.1 & 2.1 \\
\hline Minimum & 5.7 & 5.8 & 5.1 & 5.1 & 3.2 & 3.6 & 2.9 & 2.9 & 3.2 & 3.6 & 2.9 & 2.9 \\
\hline Maximum & 10 & 10 & 10 & 10 & 10 & 10 & 10 & 10 & 10 & 10 & 10 & 10 \\
\hline Observations & 15 & 15 & 15 & 45 & 24 & 26 & 26 & 76 & 39 & 41 & 41 & 121 \\
\hline
\end{tabular}

According to Table 2, the mean Tobin's Q in the Iberian Peninsula suggests that the sample firms are overvalued. However, in the Spanish market, we find the highest means for each year compared to the Portuguese market observations.

Table 2: Tobin's Q - Statistical Data.

\begin{tabular}{|c|c|c|c|c|c|c|c|c|c|c|c|c|}
\hline & \multicolumn{4}{|c|}{ Portugal } & \multicolumn{4}{|c|}{ Spain } & \multicolumn{4}{|c|}{ Iberian Market } \\
\hline & 2010 & 2011 & 2012 & $\begin{array}{l}2010- \\
2012\end{array}$ & $\begin{array}{c}201 \\
0\end{array}$ & $\begin{array}{c}201 \\
1\end{array}$ & $\begin{array}{c}201 \\
2\end{array}$ & $\begin{array}{l}2010 \\
2012\end{array}$ & $\begin{array}{c}201 \\
0\end{array}$ & $\begin{array}{c}201 \\
1\end{array}$ & $\stackrel{201}{2}$ & $\begin{array}{l}2010 \\
2012\end{array}$ \\
\hline Mean & 1.2 & 1.1 & 1.1 & 1.1 & 1.4 & 1.3 & 1.5 & 1.4 & 1.3 & 1.2 & 1.3 & 1.3 \\
\hline Median & 1.0 & 1.0 & 1.0 & 1.0 & 1.2 & 1.1 & 1.1 & 1.1 & 1.1 & 1.0 & 1.1 & 1.0 \\
\hline $\begin{array}{l}\text { Standard } \\
\text { Deviation }\end{array}$ & 0.4 & 0.4 & 0.5 & 0.4 & 0.7 & 0.7 & 1.0 & 1.0 & 0.6 & 0.6 & 0.9 & 0.7 \\
\hline Minimum & 0.7 & 0.7 & 0.5 & 0.5 & 0.7 & 0.7 & 0.7 & 0.7 & 0.7 & 0.7 & 0.5 & 0.5 \\
\hline Maximum & 2.4 & 2.4 & 2.5 & 2.5 & 3.7 & 3.8 & 5.3 & 5.3 & 3.7 & 3.8 & 5.4 & 5.4 \\
\hline Observations & 15 & 15 & 15 & 45 & 24 & 26 & 26 & 76 & 39 & 41 & 41 & 121 \\
\hline
\end{tabular}

In the Iberian market, it is possible to observe through Table 3 that all the calculated Pearson's correlations between the metrics of corporate value and diversification are statistically significant at $1 \%$.

The correlation observed between the Herfindahl Index and Tobin's Q is approximately 0,223, revealing a low positive correlation between these two variables. This value is similar to what was found in Lang and Stulz [19] and Carvalho, Maia and Barbedo [20], with a correlation of 0,26 and 0,25 , respectively. This means that, in this market, higher levels of diversification are associated with a lower Tobin Q.

Table 3: Correlation matrix between Herfindahl Index, Number of Segments, and Tobin's Q and the respective results of the hypothesis t-tests from 2010 to 2012, in the Iberian Market.

\begin{tabular}{cccc}
\hline & $\begin{array}{c}\text { Herfindah } \\
\text { 1 Index }\end{array}$ & $\begin{array}{c}\text { Number of } \\
\text { Segments }\end{array}$ & $\begin{array}{c}\text { Tobin } \\
\text { 's } Q\end{array}$ \\
\hline Herfindahl & 1 & & \\
Index & & & \\
$t$ statistic & - & & \\
$P$-value & - & & \\
Number of & $-0,824$ & 1 & \\
Segments & & - & \\
$t$ statistic & 41,946 & - & \\
$P$-value & 0,000 & - & \\
Tobin's $Q$ & 0,223 & $-0,242$ & 1 \\
$t$ statistic & $-41,983$ & $-5,727$ & - \\
$P$-value & 0,000 & 0,000 & - \\
\hline
\end{tabular}

In the Portuguese market, the results differ from the rest of the markets since Table 4 shows a practically non-existent correlation between the Herfindahl Index and Tobin's Q (-0.016), whereas in the Iberian and Spanish markets the correlation is positive, as shown in Table 3 and Table 5.

Table 4: Correlation matrix between Herfindahl Index, Number of Segments, Tobin's Q, and the respective results of the hypothesis t-tests from 2010 to 2012, in Portugal.

\begin{tabular}{cccc}
\hline & $\begin{array}{c}\text { Herfindah } \\
\text { 1 Index }\end{array}$ & $\begin{array}{c}\text { Number of } \\
\text { Segments }\end{array}$ & $\begin{array}{c}\text { Tobin } \\
\text { 's } Q\end{array}$ \\
\hline $\begin{array}{c}\text { Herfindahl } \\
\text { Index }\end{array}$ & 1 & & \\
$t$ statistic & - & & \\
$\quad$-value & - & & \\
Number of & $-0,931$ & 1 & \\
Segments & & & \\
$t$ statistic & 38,178 & - & \\
$P$-value & 0,000 & - & \\
Tobin's $Q$ & $-0,016$ & 0,0001 & 1 \\
$t$ statistic & $-38,220$ & $-6,019$ & - \\
$P$-value & 0,000 & 0,000 & - \\
\hline
\end{tabular}

In the Spanish market, the opposite occurs. In this case, as Table 5 shows, the correlation between Herfindahl Index and Tobin's Q $(0,314)$ exceeds the correlations found in Lang and Stulz's [19] and Carvalho Maia and Barbedo's [20] studies.

Table 5: Correlation matrix between Herfindahl Index, Number of Segments, and Tobin's Q, and the respective results of the hypothesis t-tests from 2010 to 2012, in Spain. 


\begin{tabular}{cccc}
\hline & $\begin{array}{c}\text { Herfindah } \\
\text { I Index }\end{array}$ & $\begin{array}{c}\text { Number of } \\
\text { Segments }\end{array}$ & $\begin{array}{c}\text { Tobin } \\
\text { 's } Q\end{array}$ \\
\hline $\begin{array}{c}\text { Herfindahl } \\
\text { Index }\end{array}$ & 1 & & \\
$t$ statistic & - & & \\
$P$-value & - & & \\
Number of & $-0,822$ & 1 & \\
Segments & & & \\
$t$ statistic & 28,580 & - & \\
$P$-value & 0,000 & - & \\
Tobin's $Q$ & 0,314 & $-0,296$ & 1 \\
$t$ statistic & $-28,605$ & $-3,398$ & - \\
$P$-value & 0,000 & 0,000 & - \\
\hline
\end{tabular}

In the second phase of the tests, where the sample is divided into three different groups of diversification, we found that the group of firms with only one segment per-formed best, exceeding the group of highly diversified firms by $34 \%$. On the other hand, its standard deviation is also higher, indicating that even though the group of highly diversified firms shows poor performance compared to the other groups, it is also the most stable and predictable, implying a lesser risk, as seen in Table 6 .

Table 6: Tobin's $Q$ for the three groups of diversification based on the Herfindahl Index. Statistical Data

\begin{tabular}{|c|c|c|c|}
\hline & $\begin{array}{l}\text { Herfindahl } \\
\text { Index } \leq 0,6\end{array}$ & $\begin{array}{c}0,6< \\
\text { Herfindahl } \\
\text { Index }<1\end{array}$ & $\begin{array}{l}\text { Herfindah } \\
1 \text { Index }=1\end{array}$ \\
\hline & $\begin{array}{c}\text { Highly } \\
\text { Diversified }\end{array}$ & $\begin{array}{c}\text { Poorly } \\
\text { diversified }\end{array}$ & Focalized \\
\hline Mean & 0,951 & 1,256 & 1,458 \\
\hline Median & 0,950 & 0,997 & 1,212 \\
\hline $\begin{array}{l}\text { Standard- } \\
\text { Deviation }\end{array}$ & 0,074 & 0,584 & 0,864 \\
\hline $\begin{array}{l}\text { Minimu } \\
\mathbf{m}\end{array}$ & 0,792 & 0,693 & 0,513 \\
\hline$\underset{\mathbf{m}}{\text { Maximu }}$ & 1,140 & 2,829 & 5,373 \\
\hline $\begin{array}{l}\text { Observati } \\
\text { ons }\end{array}$ & 21 & 50 & 50 \\
\hline
\end{tabular}

The first phase of the hypothesis tests for means (using a t-test), between the groups of poorly diversified and focalized firms, shows us that we cannot reject the null hypothesis, eliminating the possibility to make statistical inferences when comparing both groups (Table 7).
Table 7: Hypothesis test for the means of the groups of focalized firms and poorly diversified firms.

\begin{tabular}{cc}
\hline Herfindahl Index $=\mathbf{1}$ & $\mathbf{0 , 6}<$ Herfindahl Index $<\mathbf{1}$ \\
\hline Focalized & Poorly diversified \\
\hline$t$ statistic & 1,365 \\
$P$-Value & 0,176 \\
Crítical $t$ & 1,988 \\
\hline
\end{tabular}

Since the group of highly diversified firms is composed by several observations inferior to 30 , we used the Mann-Whitney's non-parametric test [23] in the rest of the hypothesis tests between the groups. Table 8 shows us that we cannot compare statistical significance using the poorly diversified firms' group. Despite that, we can reject the null hypothesis, with a statistical significance of $1 \%$, for the rest of the groups, which means that these tests reassure us that focalized firms are associated with higher levels of Tobin's Q when compared with highly diversified firms.

Table 8: Mann-Whitney's U test between the group of highly diversified firms and the rest of the groups.

\begin{tabular}{ccc}
$\begin{array}{c}\text { Herfindahl Index } \\
\leq \mathbf{0 , 6}\end{array}$ & $\begin{array}{c}\text { Herfindahl } \\
\text { Index }=\mathbf{1}\end{array}$ & $\begin{array}{c}\mathbf{0 , 6 <} \\
\text { Herfinda } \\
\mathbf{h l} \text { Index } \\
\mathbf{< 1}\end{array}$ \\
\hline Highly diversified & Focalized & $\begin{array}{c}\text { Poorly } \\
\text { diversifie } \\
\mathrm{d}\end{array}$ \\
\hline Z statistic & 4,164 & 1,493 \\
P-value & 0,000 & 0,136 \\
Critical Z & 2,576 & 1,960 \\
\hline
\end{tabular}

The quadratic relation between diversification and value was applied to the three markets, but only in Portugal statistical significance was found (1\%), which suggests that this relation is not present in the other markets of this study (Table 9). As Figure 1 and Table 9 describe, the sample of Portuguese firms originates from a concave parabola, which implies that a firm can reach a specific diversification level that maximizes its value.

(5)

$$
Q_{t, j}=-5,581+16,967 H H I_{t, j}-10,361 H H I_{t, j}^{2}+\varepsilon_{t, j}
$$

Table 9: The quadratic regression results where $Q$ is the dependent variable and the Herfindahl Index are the independent variables, using the Portuguese sample. 


\begin{tabular}{cccc}
\hline & $\begin{array}{c}\text { Coefficient } \\
\text { s }\end{array}$ & $\boldsymbol{t}$ stat & $\begin{array}{c}\boldsymbol{P} \text { - } \\
\text { value }\end{array}$ \\
\hline Constant & $-5,581$ & - & 0,010 \\
Herfindahl Index & 16,967 & 3,274 & 0,002 \\
$\begin{array}{c}\text { Herfindahl Index } \\
\wedge 2\end{array}$ & $-10,361$ & - & 0,002 \\
\hline
\end{tabular}

Figure 1. Quadratic relation between Tobin's Q and the Herfindahl Index in the Portuguese market.

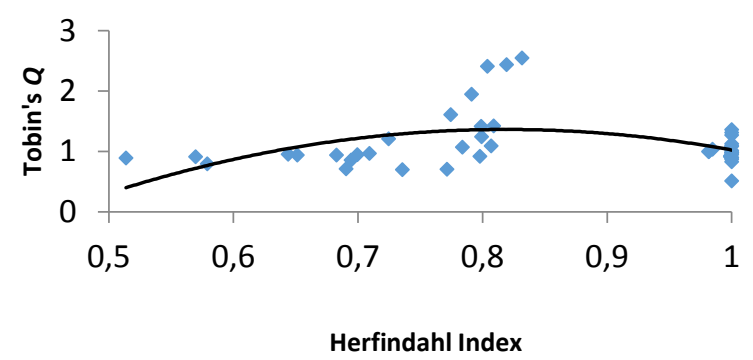

Although these results diverge from what is observed in Carvalho, Maia, and Barbedo's study [20], they agree with what is found on Markides's [17] and Santareli and Tran's [18]. If we derive Equation 5, we obtain the theoretical optimum point of diversification, 0,818 . The fact that this value is close to 1 (Herfindahl Index's maximum) indicates that, just like the Spanish and Iberian markets, higher Tobin's Q is associated with lower diversification levels. The value/diversification relationship appears to have different behaviours in each market, which can also explain the divergence of opinions in the literature.

Like in the test above, the Portuguese sample was the only one with statistical significance in the dummy variable regression. The regression includes the variables from $\mathrm{D}(2)$ to $\mathrm{D}(4)$, excluding the variables corresponding to a higher number of segments due to their high p-values, generating noise in the regression. With the due adjustments, this originates Equation 6, a result of the coefficients' interpretation and the statistical significances exposed in Table 10.

(6)

$$
Q_{t, j}=1,009+0,326 D(3)_{t, j}-0,536 D(4)_{t, j}+\varepsilon_{t, j}
$$

Table 10: Dummy regression adjusted to 4 segments applied to the Portuguese sample, with Tobin's $\mathrm{Q}$ being the dependent variable and each business segment a dummy variable.

\begin{tabular}{cccc}
\hline & Coefficients & $\boldsymbol{t}$ stat & $\boldsymbol{P}$-value \\
\hline Constant & 1,009 & 10,036 & 0,000
\end{tabular}

\begin{tabular}{lccc}
$\mathrm{D}(2)$ & 0,108 & 0,622 & 0,536 \\
$\mathrm{D}(3)$ & 0,326 & 1,778 & 0,082 \\
$\mathrm{D}(4)$ & $-0,536$ & $-3,023$ & 0,004 \\
\hline
\end{tabular}

It is possible to notice on Table 10 that there is a positive marginal increment on Tobin's Q until the third segment. However, the situation is inverted when the firm reaches the fourth segment, originating its Q's negative marginal increment (-0.536). This result may be related to what was found in the quadratic relation test described in the previous paragraphs. In other words, the optimum point of diversification present on the previous test could correspond to the segment number three in this dummy regression. Once again, this optimum point of diversification corroborates the studies by Coase [22], Markides [17], Santarelli and Tran [18], at the same time that it meets Lang and Stulz [19], that is, that the optimum point tends to correspond to a low level of diversification.

Like the divergence of conclusions found in the literature, this study shows that the impact of diversification may vary according to the market analysed. It turns out that it is not easy to say that in general diversification affects the value of a company, as there may be unique factors in each market that influence the relationship between value and diversification. With the results obtained it is difficult to generalize, given that different markets have presented different results. Studies in more markets and in different economic contexts (recession vs. expansion) will be needed to see if there are conclusions that can be generalized for all markets.

\section{Conclusion}

The samples used, Portuguese, Spanish, and Iberian revealed, on average, a low level of diversification and a slight overvaluation by the markets.

The present study also reveals that a higher Tobin's Q is associated with a higher Herfindahl Index for the samples that were used. In other words, focalized firms tend to perform better than diversified firms. This result is more evident in Spain than in Portugal, as it was shown in Pearson's correlation tests. In the Portuguese sample, we observe a quadratic behavior between the used metrics. This relation suggests that there is a specific level of diversification that maximizes the value of a firm. Besides, the dummy regression results imply that this level can be reached by operating approximately in three different segments.

Even though the relationship between diversification and value may be a negative one in 
this sample, we have to consider that this type of relationship could influence other factors, such as the economic recession

\section{References:}

[1] Tripathi, P.C. and Reddy, P.N., Principles of Management. New Delhi: Tata McGraw-Hill, 2006. ISBN: 00706005899780070600584

[2] Flamholtz E.G. and Randle, Y., Growing Pains: Building Sustainably Successful Organization,. 5th Edition. 2020. ISBN-10: 1118916409

[3] Kochanska, A., and Castanho, R.A., The Relevance of Planning to Achieve a Successful Company. A Brief Overview, Revista Científica Monfragüe Resiliente - Scientific Journal. Vol. XII (1). 2019, pp.342-355. ISSN 2340-5457.

[4] Orhan, A., Benli, V.F., and Castanho, R.A., Assessing the Systemic Risk Between American and European Financial Systems, Prague Economic Papers, Vol. 18, No. 3, 2020, pp. 487 - 502, July 2020 https://doi.org/10.18267/j.pep.756

[5] Santalo, J. and Becerra, M., Competition from Specialized Firms and the DiversificationPerformance Linkage, Journal of Finance 63 (2), 2008.

[6] Rumelt, R. P., Diversification strategy and profitability, Strategic Management Journal, 3(4), 1982, pp. 359-369.

[7] Wemerfeld, B. and Montgomery, C. A., Tobin's $Q$ and the importance of focus in firm performance, American Economic Review 78, 1988, pp. 246-250.

[8] Villalonga, B., Diversification discount or premium? New evidence from the Business Information Tracking Series, Journal of Finance, 59, 2004, pp. 479-506.

[9] Hadlock, C., Ryngaert, M. and Thomas, S., Corporate structure and equity offerings: are there benefits to diversification? Journal of Business, 74 (10), 2001.

[10] Morck, R., Shleifer, A. and Vishny, R., Do managerial objectives drive bad acquisitions? Journal of Finance, 45 (1), 1990.

[11] Scharfstein, D. S. and Stein, J. C., The dark side of internal capital markets II: Evidence from diversified conglomerates, Journal of Finance 55, 2000, pp. 2537-2564.

[12] Maksimovic, V. and Phillips, G., Do Conglomerate Firms Allocate Resources Inefficiently Across Industries? Theory and Evidence, The Journal of Finance, 57, 2002, pp. 721-767. doi:10.1111/1540-6261.00440

[13] Lebaron, D. and Speidell, L. S., Why are the parts worth more than the sum? "Chop Shop," a corporate valuation model, Federal Reserve Bank of Boston, Conference Series (31), 1987, pp. 78-101.

[14] Comment, R. and Jarrel, G. A., Corporate focus and stock returns, Journal of Financial Economics, 37, 1995, pp. 67-87.

[15] Sayrak, A. and Martin, J. D., Corporate diversification and shareholder value: a survey of recent literature, Journal of Corporate Finance, 9 (1), 2001, pp. 37-57.

[16] Marinelli, F., The relationship between diversification and firm's performance: Is there really a causal relationship? IESE Research Papers, IESE Business School, University of Navarra, 907, 2011.

[17] Markides, C., Consequences of corporate refocusing: Ex ante evidence, The Academy of Management Journal, 35 (2), 1992.

[18] Santarelli, E. and Tran, H., Diversification strategies and firm performance: A sample selection approach, Quaderni Working Paper DSE 896, 2013.

[19] Lang, L. and Stulz, R. M., Tobin's Q, corporate diversification and firm performance, Journal of Political Economy, 102 (6), 1994, pp. 1248-80.

[20] Carvalho, T. F., Maia, M. V. and Barbedo, C. H., $O$ efeito da diversificação no valor das empresas listadas em bolsa no Brasil. RAM, Revista de Administração Mackenzie, 13 (1), 2012, pp. 87-109.

[21] Tobin, J., A general equilibrium approach to monetary theory, Journal of Money, Credit and Banking, 1 (1), 1969, pp. 15-29.

[22] Coase, R. (1937), The Nature of the Firm, Economica. Ed. Blackwell Publishing 4 (16), 1969.

[23] Lehmann, E. L., Nonparametrics: Statistical methods based on rank, San Francisco: HoldenDay, 1975.

\section{Contribution of individual authors to the creation of a scientific article (ghostwriting policy)}

All the authors contributed equally in the development of the present paper. All of the phases of the paper development proper have been discussed and worked on by the authors. All authors have read and agreed to the published version of the manuscript. 


\section{Sources of funding for research presented in a scientific article or scientific article itself}

The project is funded under the program of the Minister of Science and Higher Education titled "Regional Initiative of Excellence" in 2019-2022, project number $018 / \mathrm{RID} / 2018 / 19$, the amount of funding PLN 10788423,16 and also by the Portuguese national funds through FCT - Fundação para a Ciência e a Tecnologia, I.P., project number UIDB/00685/2020

\section{Creative Commons Attribution}

\section{License 4.0 (Attribution 4.0}

International , CC BY 4.0)

This article is published under the terms of the Creative Commons Attribution License 4.0

https://creativecommons.org/licenses/by/4.0/deed.en $\underline{\mathrm{US}}$ 